\title{
AN UNNOTICED CONTRIBUTION TO DEMOGRAPHIC TRANSITION THEORY*
}

\author{
ANATOLY VISHNEVSKY, MARK TOLTS
}

\begin{abstract}
Alexander Kulischer [Alexandre Koulicher] (1890-1942), a former professor at the University of Petrograd (St. Petersburg, Russia) who emigrated to France after the Russian Revolution of October 1917, may be considered one of the pioneers of the theory of demographic transition. However, his contribution to the development of this theory has gone almost unnoticed and underrated. This article presents an intellectual biography of Alexander Kulischer and analyses his views on the demographic transition (demographic revolution), as he expressed them in his publications in German and in French in the first half of the 1930s. Two of these forgotten publications written in French are republished in the appendix to the article.
\end{abstract}

Key words: history of demography, demographic transition, demographic revolution, fertility, mortality, migration, Alexander Kulischer [Alexandre Koulicher].

As noted by the British historian and demographer Simon Szreter, the demographic transition theory was born twice [Szreter 1993: 661]: in the first decades of the 20th century and in the 1940s. If this observation is true, then our article covers the first birth of the theory, because the protagonist of this article, unfortunately, did not survive the 1940s.

There is a canonical story of the early life period of the demographic transition theory, which links its origin above all to two names: Adolphe Landry and Warren S. Thompson. In fact, already in a 1909 article [Landry 1909] Landry drew attention to the emergence of a "new demographic regime" requiring a new theory of population, but, as he wrote at the time, "this new theory of population is not, in truth, yet fully developed, it is still in the making" [Landry 1982: 183]. The theory of demographic transition became this "new theory", which then could be only vaguely seen in mentioning a "new demographic regime", but subsequently was significantly developed in Landry's book “The Demographic Revolution”, published in 1934 [Landry 1934], and in a more concise form in a paper of the same name a year before [Landry 1933].

As for Thompson, his first brick in the building of the future theory was laid down in a 1929 article [Thompson 1929] in which he identified three groups of countries differing in their birth and death rates and, consequently, in the natural increase of the population. Like Landry, he suggested that as they industrialise, all countries will drift in the direction of the group with low levels of mortality and fertility.

Anatoly G. Vishnevsky (avishnevsky@hse.ru), NATIONAl ReSEARCh University Higher School Of Economics, RUSSIA.

MARK Tolts (mtolts@huji.ac.il), HEBrEw UNIVERSiTy OF JERUSALEM, ISRAEL.

AUTHORS ARE LISTED ACCORDING TO THE CYRILLIC ALPHABETICAL ORDER AS THEY APPEAR IN THE BELOW-MENTIONED ORIGINAL RUSSIAN ARTICLE.

* The original article in Russian was Published in DEMographic RevieW, 2015, 2(4): 6-34.

URL: HTTPS://DEMREVIEW.HSE.RU/EN/2015--4/179982792.HTML

THE STUDY WAS PARTLY CARRIED OUT WITHIN THE FRAMEWORK OF THE BASIC RESEARCH PROGRAMME AT THE NATIONAL RESEARCH UNIVERSITY HIGHER SCHOOL OF ECONOMICS (HSE) IN 2013-2015. 
There are sometimes proposals to expand the circle of the theory's pioneers. For example, Szreter proposes to include in their number Lujo Brentano, Alexander Morris Carr-Saunders, Thomas Henry Craig Stevenson and Leon Rabinowicz [Szreter 1993: 694]. Our task, however, is not to discuss the whole range of issues relating to the early history of the demographic transition theory. We will just dwell briefly on the last of these authors, because he is the only one who is widely known to Russian demographers and precisely as one of the earliest developers of the theory.

As pointed out by Szreter, he learned about the contribution of Leon Rabinowicz, the author of the book published in 1929 in Paris, "Le problème de la population en France précèdé d'une histoire générale de la population. Étude de sociologie de la population" [Rabinowicz 1929], from an article by the Czechoslovak researcher Alena Subrtova [Subrtova 1984], to which his attention was drawn by Jean Bourgeois-Pichat [Szreter 1993: 694]. However, a much earlier article by Subrtova came to the attention of the Russian demographer Vladimir A. Borisov, who published a paper based on it titled "One more date of the origin of the demographic revolution theory" [Borisov 1986].

In fact, one of the sections of Rabinowicz's book is called "La révolution démographique", and since this book appeared earlier than the publications of Landry, which used this expression, Subrtova and Borisov saw in this a reason (in our opinion, insufficient) for considering its author as one of the pioneers of the theory of demographic transition.

Judging by the publications of Subrtova, Borisov and Szreter, they knew little about Rabinowicz when they referred to his book. They knew no more than that he was born in Poland and had published his book in Paris at the age of 28. In late 1986, after the publication of Borisov's paper, one of the authors of the present article met at a conference in Berlin with Eugene Grebenik, editor of the British journal "Population Studies", and asked him whether he had heard anything about Leon Rabinowicz. The answer was unexpected: Grebenik not only had heard of him, but knew him personally. Leon Rabinowicz was still alive: he had just changed his name. Now his name was Leon Radzinowicz - since 1970, Sir Leon Radzinowicz. He had had a distinguished academic career and gained an international name in the field of criminology, and he had become the founder and first director of the Institute of Criminology of the University of Cambridge. After his book was published in 1929, he never again turned to demography.

When this information reached Borisov, he wrote a letter to Leon Radzinowicz and received a reply from him. In turn, Subrtova, in response to a letter from Borisov, said that she, too, knew of the existence of Leon Radzinowicz. He was, she declared, still alive in 1985 [Correspondence 2007]. (Leon Radzinowicz died in 1999 at the age of 93).

In his reply to Borisov, Leon Radzinowicz wrote in particular: "I continue to be surprised that I was the first to use this expression (demographic revolution). It seems to me quite natural to use it" [Correspondence 2007]. In this he was probably right.

Borisov wrote Leon Radzinowicz another letter in which he asked if he knew Adolphe Landry's book. He received no reply to the letter. However, it seems to us unlikely that Landry did not know about a book published in Paris and dedicated to the problems of France's population. It is possible that this book prompted him to use "demographic revolution" as the title of his 1933 
article, and then of his 1934 book. Nevertheless, the use of a felicitous expression and the formulation of a fruitful scientific idea are not the same thing.

Leon Rabinowicz (Radzinowicz) was also not the first author to use the expression "demographic revolution". The earliest use known to us is by the Soviet (Ukrainian) demographer Arseniy Khomenko in a pamphlet published in 1925 in Ukrainian [Khomenko 1925], where, referring to the change in birth and death rates in Ukraine during the war and revolutionary upheaval, he writes: "As a result of all this, an entire demographic revolution is taking place" [Khomenko 1980: 104]. In this case, by the word "revolution", then in the air, the author just wanted to emphasise the large scale of the changes taking place, but he did not pretend to suggest any theoretical generalisation. Approximately the same was the case with Leon Rabinowicz.

It is difficult to agree with Subrtova when she writes that he was "the first to use the term 'demographic revolution' in the conceptual sense now used by most demographers" [Subrtova 1984]. Most demographers use it in the context of the demographic revolution theory or the demographic transition - depending on who prefers which - but it always concerns, as Subrtova herself notes, citing Zdenek Pavlik, the upheaval which changed the "quantitative and qualitative nature" of reproduction, "which is most pronounced in the changes in fertility and mortality levels, in the age structure of the population" [Pavlik 1981: 21]. Leon Rabinowicz writes about fertility and mortality and their changes, but sees no "revolution" in this. "We can, without fear of exaggeration," he wrote, "say that the industrial revolution caused a demographic revolution. We will look at it from three perspectives: 1) the overall growth of the population of England; 2) the movement of population centres; 3 ) the urbanisation of the country" [Rabinowicz 1929: 139]. Here the word "revolution" is used to indicate the importance and magnitude of what was happening with the population. This usage is quite justified, but it does not contain the generalisation which spurred the development of the theory.

\section{2}

Now we want to extend the list of pioneers of the demographic transition theory with another great name, which, although not entirely unknown to demographers, is never mentioned in connection with this theory. And yet we are talking about a man who not only literally in just a few words outlined the meaning of what is now called the "demographic transition", but also astutely pointed to the future global sense of this theory, something which none of his contemporaries did.

The historian and economist Joseph Kulischer is well known in the scholarly world as the author of the classic work "History of economic life in Western Europe", which was republished in Russia many times ${ }^{1}$ and translated into many languages (e.g. German, Italian, Japanese, etc.). Also widely known in the West is the book by his brother, Eugene Kulischer, "Europe on the move: war and population changes, 1917-1947” [Kulischer E. 1948], who, incidentally, introduced the term "displaced persons" [Tolts 2015a].

\footnotetext{
${ }^{1}$ The latest edition in Russian is [Kulischer J. 2012].
} 
Less well known, however, is that Joseph and Eugene Kulischer had a younger brother, Alexander, who was also a distinguished scholar. A. Kulischer was born in St. Petersburg on February 9 (21), 1890. ${ }^{2}$ In 1907 he graduated there with honours from the St. Anne Gymnasium (Annenschule) [Delo ... 1907]. Alexander, like his brothers, was tremendously influenced by their father, Mikhail Ignatyevich Kulisher (better known in world scholarly literature as Michael Kulischer), who was a prime example of a polymath [Tolts 2015b]. He was well known in Russia as an ethnographer, historian and sociologist, and not only among specialists; Michael Kulischer published frequently in popular journals. Many of his articles were also published in German academic journals, which made their author famous outside Russia.

Alexander was the youngest in the Kulischer family. Like all his brothers, and before them his father, he was educated in the Law Department of St. Petersburg University, from which he graduated in 1911 [Delo ... 1907]. Later, when describing the scholarly path of each of the Kulischer brothers, contemporaries always called them disciples of the famous Russian sociologist Maxim Kovalevsky, ${ }^{3}$ who taught at the university where they studied. While at the university, Alexander, like his brother Eugene, was an active participant in the student circle of the prominent lawyer and sociologist Leon Petrazycki (Petrazhytski) [Shul'govskiy 1910]. Out of this group emerged the most prominent Russian social scholars well-known in the West: Pitirim Sorokin, Georges Gurvitch, Nicholas Timasheff, Nikolai Kondratiev [Golosenko, Serbenko 1999].

After graduating from university, Alexander trained for two years at Oxford under the scientific guidance of the Russian-British historian and jurist Paul Vinogradoff. Subsequently, "he returned to Russia with a well-deserved reputation as the best expert in English constitutional law" [Gurvitch 1942: 374]. Alexander's collaboration with his Oxford mentor continued after his departure from England. So, upon publication in 1915 of one of his books, the scholar mentioned Alexander Kulischer among those who helped him "with the reworking of the English edition into the Russian text" [Vinogradoff 2014: 4]. When Vinogradoff died, Alexander published an extensive obituary [Kulisher A. 1925].

In those years, the political system of England and the problems of Ireland's selfdetermination were at the center of Alexander Kulischer's scholarly interests. He devoted two articles to these problems: "The national unity of England and Home Rule" and "Irish Home Rule and English federalism", which were then published together under the title "The autonomy of Ireland" [Kulisher A. 1915].

Alexander Kulischer's knowledge in constitutional law turned out to be in demand after the February Revolution of 1917, when he took an active part in the formation of a new concept of the country's higher authorities [Vremennoye Pravitel'stvo i Uchreditel'noye Sobraniye 1928]. In addition, Alexander Kulischer was a member of the Commission on the reform of local selfgovernment [Bayguzina 2006: 404]. It was his finest hour as a scholar of law. It is clear, however,

\footnotetext{
${ }^{2}$ Made clear from the student records of Alexander Kulischer [Delo ... 1907]. The authors are grateful to Anatoly I. Chayesh for providing data from this source.

${ }^{3}$ In the library of this scholar, there is a reprint of an article by Alexander Kulischer with these words: "To my dear Maxim Maximovich Kovalevsky, from his student, the author" [Matiyeva, 2008: 56].
} 
that all this work was in vain, as by the end of the year power in Russia had been seized by supporters of a completely different concept of the State.

Alexander, like other members of his family, was extremely critical of the 1917 October upheaval. All the Kulischers belonged to the Constitutional-Democratic Party, which was outlawed after the Bolsheviks came to power. Soon his brother Eugene was forced into hiding in Finland, then in 1918 he moved to Kiev [The Gazette 1942]. In December 1919, Joseph, the eldest of the Kulischer brothers, was arrested by the Cheka (State Security under the Bolsheviks); soon, however, he was released per the request of the university where he worked [Vinogradov 2003: 228]. Three months before that, in September 1919, Alexander was arrested alongside a large group of Petrograd (St. Petersburg) opposition intelligentsia, but was released [Sorokina 2003: 357].

The following year, Alexander could escape arrest only by fleeing Petrograd, where a Cheka ambush was already waiting for him in his apartment [Kulisher A. 1927a]. Thus ended his work at the University of Petrograd (St. Petersburg), where he was a professor. In July, Alexander, as he later wrote, made his way with great difficulty to Kharkov and then to Kiev [Kulischer A. 1921: 36], where he was reunited with his brother Eugene. From there began a hazardous journey to the West. They left their homeland, now in the hands of the Bolsheviks, at the end of 1920.

Once abroad, Alexander Kulischer vigorously resumed his research activity. In 1921, shortly after his arrival in Berlin, he published in German his book "The Essence of the Soviet State" [Kulischer A. 1921]. ${ }^{4}$ This book received rave reviews even from someone as far from his political views as Eduard Bernstein, a prominent figure in German Social Democracy [Bernstein 1922]. Two years later, a book by Alexander Kulischer about young Benjamin Disraeli [Kulisher A. 1923] was published in the same city in two translations.

In 1923, the Russian Scientific Institute opened in Berlin. Its academic council included, along with other well-known scholars in exile, Alexander Kulischer [Russkiy Berlin 2003: 287]. However, this institution would not become his place of work. Alexander Kulischer made persistent attempts to find a teaching position at any university, even across the ocean, but they all failed. Edward A. Ross, a well-known American sociologist, actively engaged in the fate of Russian scholars in exile (it is he, in particular, who paved the way to the United States for Pitirim Sorokin), recommended Alexander Kulischer to eighteen American universities [Doykov 2009: 124]. Unfortunately, all his efforts ended in vain; not even his good knowledge of English helped. Most likely, it was a question of his origin: "Jews ... were excluded from many faculty positions in American universities throughout the 1920s and beyond" [Rabkin 2015: 68]. ${ }^{5}$

In the very same year, 1923, Alexander Kulischer moved to Paris and started working in the most authoritative newspaper of Russian emigration - "Posledniye novosti" [The Latest News], run by the well-known historian and former Minister of the Russian Provisional

\footnotetext{
${ }^{4}$ In the publications of Alexander Kulischer in different languages, the spelling of his surname varies: Kulischer in German, Koulicher in French and Koulisher in English.

${ }^{5}$ Not long before his death, Alexander Kulischer was awarded a position in The New School for Social Research, though it happened too late to change his destiny (Gurvitch 1942).
} 
Government, Pavel N. Milyukov. Until its closure in 1940, Alexander was one of the leading columnists (some of the materials he signed under the pseudonyms Junius and M. Alexandrov, and still others he published as unsigned editorials). The role of Alexander Kulischer in the newspaper was so noticeable that opponents called it the "Milyukov - Kulischer organ" (e.g. [Vozrozhdeniye 1936]). Thus, the abilities he inherited from his father proved auspicious: in 18801886, Michael Kulischer directed the publication in Kiev of one of the best Russian provincial newspapers [Tolts 2015b].

In Paris, Alexander Kulischer lectured in the Russian department of the law faculty of the Sorbonne and in the Franco-Russian Institute of Social and Political Science, as well as in several other educational institutions and community organisations. However, in his publications in foreign languages, he always pointed out his former affiliation with the University of Petrograd. Alexander Kulischer was an elected board member of the Russian Academic Union in Paris [Serkov 2001: 443-444]. At the same time, he enthusiastically participated in various political endeavours of both all-Russian emigration and its Jewish part.

Alexander Kulischer's father had worked for more than forty years on the problems of migration and left an unfinished manuscript in German titled "Wars and resettlements" [Tolts 2015b]. Once in exile, his youngest son did not forget the legacy of his late father. In 1924, an article titled "The theory of movement of peoples and the civil war in Russia" by Alexander Kulischer appeared in a French academic journal [Koulicher A. 1924]. In this article, Michael Kulischer's migration concept was presented in the form in which it was formulated in his unfinished manuscript, and based on this concept the author gave a novel interpretation of postrevolutionary events in Russia.

Gradually, Alexander Kulischer began to give more and more attention to research on migration topics and population issues, and to lectures on these topics. At the first World Population Conference (Geneva, 1927), where he was listed as a representative of Russia (and once as a representative of the USSR), Alexander Kulischer delivered a report, "Some aspects of the migration problem" [Koulisher A. 1927c], and participated actively in a debate on migration issues. It is interesting that his statements in 1927 have not lost their relevance today and, not without reason, continue to attract the attention of experts (e.g. [Bashford 2007]).

Apparently, around this time began the close collaboration in the field of migration studies between Alexander and Eugene Kulischer. The first evidence of this collaboration was their joint participation in the 6th International Congress of Historical Sciences (Oslo, 1928), where, due to objections from the Soviet delegation, Alexander Kulischer and other Russian émigré scholars were no longer allowed to represent their country - something what they had wanted [Bocharova 1998: 97]. Each of the brothers gave a report there in a personal capacity [Koulicher A.1928; Kulischer E. 1928].

In 1932, the brothers published in German the book "War and migration. World history as peoples' movements" [Kulischer A., Kulischer E. 1932]. The Kulischers' theory of migration was for the first time presented in full, and the examination of the history of mass population movements in Eurasia spans from the 7th to the early 20th centuries. This book provoked numerous responses of contemporaries (e.g. [Milyukov 2015]). Its materials would later be widely used by many researchers, including Fernand Braudel in his classic work "Civilization and 
Capitalism, 15th-18th Century", in which he characterized the brothers as "two distinguished historians" [Braudel 1992: 97].

For our topic, it is important that it is precisely in this book a concept that can be called nothing but an exhaustive, yet concise statement of the idea of demographic transition is first formulated. We will return to this issue, but let us first finish our brief biographical sketch.

Alexander Kulischer did not lose interest in his original profession (jurisprudence), and in the first half of 1930 he published in prestigious law journals three French-language articles: "Les quatre constitutions de l'Angleterre" [Koulicher A. 1932], "La multiplicité des sources en droit constitutionnel" [Koulicher A. 1934a] and "La démocratie anglaise et le droit de dissolution" [Koulicher A. 1935]. Contemporaries evaluated the works in this cycle quite highly as "a remarkable study" [Hessen 2011: 96], "a sketch of absolutely exceptional brilliance" [Gurvitch 1942: 374] and "a brilliant study" [Dahl 1936: 166].

Yet these publications, which drew the attention of legal scholars, were rather a tribute to the past. His longtime friend Georges Gurvitch, who knew Alexander Kulischer well, said: "Over the years he became more fascinated by sociology. The problems of demography and migration of peoples especially fascinated him" [Gurvitch 1942: 374].

In 1937, the brothers began working on a new book on migration in Europe during the First World War and in the 1920s and 1930s. This book was supposed to be a continuation, the second volume of their joint work published in German in 1932. Authors of a survey of the refugee situation in Europe were familiar with one of the early versions of the manuscript, and they used its materials in their fundamental report [Simpson 1939: 64]. As a well-informed and authoritative witness wrote, the brothers managed to finish this book: "The second volume in French, which predicted the war, had been prepared for publication. The occupation of Paris prevented its appearance" [Gurvitch 1942: 375]. ${ }^{6}$

The brothers decided to flee occupied France. However, in the fall of 1941 Alexander Kulischer was arrested by the Vichy authorities when crossing into the "Free Zone". He died in February $1942^{7}$ in the Vichy internment camp of Noé in circumstances that have still not been determined [Tolts 2014].

\section{3}

Returning to the book by Alexander and Eugene Kulischer, let us cite the place of interest to us.

"The process of 'modernization' of the population, which is observed in different countries at different times, can proceed at different paces, but still in its general outline is always the same, and it seems, is necessarily associated with the

\footnotetext{
${ }^{6}$ As already mentioned, Eugene Kulisher published in the United States the book "Europe on the move: war and population changes, 1917-1947" [Kulischer E. 1948]. Its first part, the biggest in size, describes in detail the migration process in this part of the world before the Second World War. There is no doubt that the basis for it was an unpublished manuscript by the brothers in French. Alexander Kulischer's contribution to this part of the book becomes even clearer if we take into account the testimony of a well-informed expert that many of the materials used in it concerning Russia and the Soviet Union were simply absent in the United States [Gordon 1949]. Therefore, the younger brother's role in the creation of the book is apparently still underestimated by specialists.

${ }_{7}^{7}$ Two close dates are given in the available sources: February 6 and 13, 1942.
} 
penetration of modern culture in any given country. It includes a reduction of both mortality and fertility, with, however, the first for some time decreasing by more than the second, resulting in a period of an excessive increase of births, a rapid accumulation of the population mass and an obvious 'overpopulation' visible to all. The latest experience of the most culturally developed Western countries seems to indicate that an increasing decline in fertility will eventually catch up with a reduction in mortality, and that all this development will end in a stationary state with low values of both coefficients. This process can be explained by attributing the reduction in both mortality and fertility to the same cause, whether it is an increase in wealth or the enlightenment, which affects both health care and hygiene on the one hand, and the new 'sexual morality' on the other. We can also assume the existence of a causal relationship between a fall in mortality and a decrease in fertility, given that a decrease in mortality leads to a strongly progressive development of the population, in which either opportunities to feed itself must expand rapidly, or a tendency to maintain its standard of living by means of keeping families small must arise. In any case, mass migrations act as a corrective tool during a period of excessively high fertility; they reduce overcrowding, thanks to which it becomes possible to preserve the mortality rates already achieved and to make the transition from the old adaptation of the population to the conditions of existence by means of a 'carnage of death' to the new adaptation by means of a 'responsible attitude towards procreation'” [Kulischer A., Kulischer E. 1932: 139$140] .8$

Although the book from which this quote is taken has two authors, the positions formulated therein belong of course to Alexander Kulischer. This is confirmed by two of his other forgotten publications in French, which are presented in the appendix to this article.

One of them is the summary of the report at the 7th International Congress of Historical Sciences held in Warsaw in 1933. In this brief synopsis, there is a very clear description of the stages of the demographic transition, as if it had been borrowed from a modern encyclopedia.

\footnotetext{
${ }^{8}$ In the original the quotation reads as follows: «Der Prozess der "Modernisierung" einer Bevölkerungsentwicklung, der in verschiedenen Ländern zu verschiedenen Zeiten einsetzt und sich in einem verschiedenen Tempo abspielt, aber dennoch überall in den Hauptzügen derselbe bleibt und mit dem Eindringen der modernen Kultur in ein Land notwendig verbunden zu sein scheint, besteht in einem Rückgang sowohl der Mortalität als auch der Natalität, wobei aber in der Regel die erstere eine Zeitlang schneller sinkt als die letztere, wodurch eine Periode steigender Geburtenüberschüsse, eines raschen Anhäufens von Bevölkerungsmassen und einer sichtbaren und allgemein empfundenen "Übervölkerung" entsteht. Die jüngste Erfahrung der kulturell führenden Völker des Abendlandes scheint darauf hinzudeuten, dass am Ende das Sinken der Sterblichkeit doch von einem immer schnelleren Geburtenrückgang eingeholt wird und dass der Abschluss der ganzen Entwicklung in einem stationären Zustand auf der Basis eines niedrigen Niveaus der beiden Faktoren bestehen muss. Man kann diesen Prozess dadurch erklären, dass man den Rückgang sowohl der Mortalität als auch der Natalität auf dieselbe Ursache zurückführt - sei es die Hebung des Wohlstandes, sei es die Aufklärung, die sich dort in Medizin und Hygiene, hier in der "neuen Sexualmoral" auswirkt. Man kann auch einen ursächlichen Zusammenhang zwischen dem Sinken der Sterblichkeit und dem Geburtenrückgang annehmen, wenn man berücksichtigt, dass eine Verminderung der Sterblichkeitsrate eine stark progressive Bevölkerungsentwicklung herbeiführt, bei der entweder der Nahrungsspielraum immer schneller ausgeweitet werden oder eine Tendenz zur Sicherung des standard of life durch Kleinhaltung der Familien einsetzen muss. Jedenfalls sind es aber die Großen Wanderbewegungen, die in der Periode der steigenden Geburtenüberschüsse als ein Korrektiv wirken, die Übervölkerung lindern, wodurch erst die Beibehaltung der erreichten Besserung in der Sterblichkeitsrate ermöglicht und der Übergang von der alten Anpassung der Bevölkerung an den Nahrungsspielraum durch "Schlachthaussterblichkeit" zur neuen Anpassung durch "verantwortungsbewusste Zeugung" überbrückt wird».
} 
"In the first phase, the population grows faster and faster, thanks to a long-term reduction in mortality. Fertility also starts to decline, but with some lag, and its decline begins to slow down such that the excess of births is always increasing and there is a veritable 'overflow' of the country. Over time, the growth [of people] is more and more inhibited as a result of the drop in fertility catching up with that in mortality, although mortality also continues to decline. The relative increase is reduced, although the absolute number continues to grow. In the end, there is a stunning decline in fertility, which tends to suppress any excess of births and even portends a population decline" [Kulischer A. 1933]. ${ }^{9}$

To this we must add the author's clear understanding of the universality of the process and of the vector of its diffusion through Europe - from west to east. The interpretation of the French version of demographic development in the 19th century as a special case that nonetheless fits into the overall scheme of development is now widely recognized, but in the early 1930s, this was not nearly as obvious.

However, the most interesting is another publication of Alexander Kulischer - his review of "La révolution démographique" by Adolphe Landry [Landry 1934], which appeared in the same year that the book was published [Koulicher A. 1934b]. This very positive and benevolent review contains at the same time some criticisms that indicate that the reviewer has his own welldeveloped position that allows him to speak with the author of the book on equal footing.

Noting that the scholarly level of Landry's book "is far superior to most of what has been written by representatives of the natalist school", Alexander Kulischer immediately distanced himself from "natalism" as from a "prejudice". However, his positive assessment of the book is based on the fact that the author, in spite of his prejudice, presents facts that could destroy this prejudice.

Although Landry was concerned about the decrease in fertility, which, it seemed to him, leads to depopulation, he, remarks Alexander Kulischer, "without a backward glance describes the former, 'primitive' mode, in which 'balancing of the size of the population with its economic resources is provided by mortality - including mortality as a result of universal famine and pestilence"'. There is no turning back, and further arguments of the review's author anticipate the extant debate among demographers about the ability of the demographic revolution (demographic transition) to lead to sustainable reproduction of the population and to avoid depopulation in conditions of unrestricted freedom of procreative choice.

What matters is not the way he responds to this question (to which there is now no generally accepted answer), but the way he formulates his response. Alexander Kulischer considered the demographic revolution as a self-completing process as a result of which the equilibrium between fertility and mortality, upset by the "revolution", is restored to a "steady state". He too, of course, has no convincing arguments in favour of the fact that fertility cannot fall below the equilibrium point, but he is not worried by this question. Alexander Kulischer draws attention to the fact that while demographers worry about the future of fertility, the world takes advantage of the reduction

\footnotetext{
${ }^{9}$ Unfortunately, this publication of Alexander Kulischer went almost unnoticed. We know only of one reference to it in the context of the history of the study of demographic cycles [Kula 1950: 479].
} 
in mortality, which overtakes the decline in fertility, as a result of which the number of people on Earth greatly increased over the 19th century (though apparently did not actually double, as he believed in accordance with the notions of his day).

Alexander Kulischer considers the demographic revolution described by Landry universal - with the same certainty as expressed by Dudley Kirk ten years later with respect to the demographic transition [Kirk 1944: 29]. Alexander Kulischer's understanding of the demographic changes as universal processes was likely inherited from his father. Michael Kulischer, in his book "Essays on comparative ethnography and culture", already stressed that "the general scheme of motion is the same for all peoples" [Kulisher M. 1887: X]. This view, which he first expressed in the Russian press in the late 1870s, was met, per the testimony of a contemporary, with quite fierce objections from the adherents of national "uniqueness" [Vengerov 1919: 120].

It is curious and somewhat surprising that, when comparing the French and English trajectories of development (the latter was followed by other European countries), Alexander Kulischer not only emphasises that this is the issue of two different versions rather than two different patterns of the transition (il ne s'agit pas de deux stages, mais de deux variantes), but also prefers the French version. He sees the advantage of this version in the synchrony of the reduction in mortality and fertility, and sees great danger in the lagging of the decline in fertility behind that in mortality, which did not exist in France. ${ }^{10}$ It is truly amazing that in the intellectual climate of Europe of that time, permeated by the fear of depopulation, he could argue with such penetrating clarity that the "danger of uncontrolled growth of surplus population is now more substantial than the distant prospect of the shrinking of the human race as a result of fertility decline" [Kulischer A. 1934b: 258].

In a careful reading of the review, whose intent is purely scholarly, it is also impossible not to see an attempt to understand not only the new demographic realities, but also the political confusion and political speculations engendered by them - attempts to reconcile the incompatible, that is, the fear of depopulation and the fear of overpopulation. "To such an extent," he writes, "that we see today, as in some European countries, the authorities, intellectuals and 'national' democrats shouldered a double task: to convince people of the absolute need to find an exit for the population, 'suffocating' more and more within its borders, to prepare to conquer these exits at the expense of the aged or of 'inferior' races ... and at the same time to preach and conduct a policy of unfettered 'natalism', ruled by an insane fear that the 'ravages' of the 'demographic revolution' would soon $<\ldots>$ eliminate both the means and the motives for expansionist undertakings" [Kulischer A. 1934b: 259]. Recall that the idea of solving the problems of a rapidly growing population through the expansion of "living space" was clearly articulated in "Mein Kampf", and that Hitler was already in power by this time. At the same time, in "Mein Kampf" a negative attitude to birth control was clearly expressed. All of this was of course well known to Alexander Kulischer, as he headed the political section of "Posledniye novosti" [The Latest News].

The relevance of the context of the 1930s has long ceased to exist, but the relevance of the warning about the "danger of uncontrolled growth of surplus population" turning into a global

10 The French demographic tradition has always seen the same distinctions in the opposite way, interpreting the comparison of the French and English versions not in favor of France (e.g. [Sauvy 1963: 78-79]). 
population explosion has not only lingered, but has grown much more acute decades after the death of Alexander Kulischer.

Worthy of special mention is another feature of Alexander Kulischer's examination of all the problems of demographic transition. We have already cited words, somewhat unusual for reflections focused on the demographic transition, from the 1932 book, that "mass migrations act as a corrective tool during a period of excessively high fertility". The poorly understood fertility decline in the twentieth century made a terrifying impression on the entire European society associated with demography's increased interest in fertility problems; migration as a subject of scholarly interest faded into the background. As David Coleman rightly wrote, "Until recently, migration has typically been regarded as the 'weak sister' of modern demography" [Coleman 2006b: 19]. Content analysis of the four leading European demographic journals for 1997-1999 showed that migration as a subject of study was dealt with significantly less often than fertility and mortality, and "migration as a factor (a variable) contributing to population size was treated only marginally, which is not the case with regard to fertility and mortality" [Hoffmann-Nowotny 2000: 77-78]. However, then the situation began to change rapidly, as migration began to attract more and more attention. Coleman, with his concept of "the third demographic transition" [Coleman 2006a], contributed to the relatively recent inclusion of migration issues into the set of central issues of the theory of demographic transition; unfortunately, he did it somewhat one-sidedly because he sees "the third demographic transition" only from the perspective of countries accepting migrants.

Meanwhile, Alexander Kulischer, in contrast, originally viewed the demographic transition through the eyes of a scholar of migration, heavily influenced by his father, who had developed the theory of migration as a part of general population dynamics theory [Koulicher A. 1924].

In his review of Landry's book, Alexander Kulischer recalls the role played by emigration in the 19th century. In all European countries except France, "birth control affected initially only cities that had been inundated by people from the countryside, who still lived by the 'laws of nature' and had avoided the effects of this 'primitive regime' only thanks to this migration, as well as to emigration overseas" [Kulischer A. 1934b: 258].

However, he had touched on this topic earlier and in greater detail. In his intervention at the World Population Conference of 1927, Alexander Kulischer said: "One considers an isolated country and says such and such is its birth rate, such its growth, such its natural and artificial resources. If one reflects for a minute, however, one sees all at once that this problem of an isolated population does not exist. In reality, the whole area within which migration is possible is a unit" [Koulisher A. 1927b: 102].

In his main presentation at the Congress in 1927, Alexander Kulischer begins with the assertion (similar to D. Coleman's statements at the beginning of the 21 st century) that the importance of migration was underestimated in demographic theory [Koulisher A. 1927c: 305]. Pointing to a number of historical examples of the extremely important role of migration as a component of population dynamics (and stressing every time the hardly peaceful nature of large migrations - another point in common with Coleman [2006a: 419]), he comes to a conclusion which seems to have been formulated today: 
"As the period of the exceptionally rapid increase of food resources and of the 'open door' for migrations seems to be closed, birth control might be perhaps an alternative to the return to the ancient conditions if it prevailed universally. But we must wait a long time before this solution is universally adopted. In the meantime, the richer nations, which are also those with a sharply declining birth rate, if they refuse to admit the surplus population of the poorer countries, will be forced to help the potential emigrant populations in finding a living at home" [Koulisher A. 1927c: 309].

Summarizing, we can say that Alexander Kulischer, already in the late 1920s and early 1930s, had - and repeatedly expressed - a clear conception, in many respects ahead of its time, of an array of demographic changes grouped today under the concept of a "demographic revolution" or "demographic transition". As he understood them, these universal changes, inevitable for all countries, concerned all three main demographic processes (mortality, fertility and migration), and determined the nature of their interaction: a fall in fertility is a consequence of a fall in mortality, and the lagging of the first behind the second leads to excessive population growth, which to some extent can be controlled through migration.

It is also important that Alexander Kulischer not only developed the general scheme of demographic changes, but also expressed awareness of related problems. For example, one cannot but marvel at his insight into the impossibility of decreasing fertility rapidly everywhere and at the same time the concomitant impossibility of countering the excess of population in poor countries with emigration.

At the same time, his view of the demographic revolution is more optimistic than that of Landry. Alexander Kulischer does not share Landry's concerns about the devastating threats allegedly posed by the demographic revolution; with a touch of irony, he mentions Landry's reflection that the Roman Empire collapsed because of declining fertility, and he calls to "reject the solidarity of interests of the 'populationists' of all countries and take a humanistic point of view...which ardently yearns...for the soonest possible triumph of the "demographic revolution"'. [Kulischer A. 1934b: 259].

\section{REFERENCES}

Bashford A. (2007). Nation, empire, globe: the spaces of population debate in the interwar years // Comparative Studies in Society and History. 49(1): 170-201.

Bayguzina R.N., ed. (2006). Administrativnye reformy v Rossii: istoriya i sovremennost' [Administrative reforms in Russia: History and modernity]. Moskva: ROSSPEN.

Bernstein E. (1922). Sowjet-Rußland als Experiment der Geschichte // Die Glocke. 8/1(7): 180187.

Bocharova Z.S. (1998). Sovremennaya istoriografiya rossiyskovo zarubezh'ya 1920-1930-kh godov [Contemporary historiography of the Russian emigré community in the 1920s and the 1930s] // Otechestvennaya istoriya [National history]. 1: 91-102.

Borisov V.A. (1986). Yeshche odna data vozniknoveniya teorii demograficheskoy revolyutsii

[One more date of the origin of the demographic revolution theory] // Sotsiologicheskiye issledovaniya [Sociological studies]. 3: 209-213. See also: Borisov V.A. (2007). 
Demograficheskaya dezorganizatsiya Rossii: 1897-2007. Izbrannyye demograficheskiye trudy [The demographic disorganisation of Russia: 1897-2007. Selected demographic works]. Moskva: NOTA BENE: 490-497.

Braudel F. (1992). Civilisation and capitalism, 15th-18th century. Vol. I: The structures of everyday life. Berkeley - Los Angeles: University of California Press.

Coleman D. (2006a). Immigration and ethnic change in low-fertility countries: a third demographic transition // Population and development review. 32(3): 401-446.

(2006b). Migration as a primary force in human population processes // Caselli G., J. Vallin, G. J. Wunsch; [et al.]. Demography: analysis and synthesis. Vol. 3. Amsterdam [etc.]: Elsevier: 19-40.

Dahl S. (1936). Den engelska parlamentarismens kärnpunkt // Statsvetenskaplig Tidskrift för Politik, Statistik, Ekonomi. 39(2): 166-168.

Delo (1907). Imperatorskovo SPb. Universiteta o studente Aleksandre Mikhayloviche Kulishere [Records of the Imperial St. Petersburg University concerning the student Alexander M. Kulischer] // TsGIA (Central State Historical Archive) St. Petersburg. Fond [Collection] 14. Opis' [Inventory] 3. Delo [File] 50969.

Doykov Yu.V. (2009). Pitirim Sorokin. Chelovek vne sezona. Biografiya [A man out of season. Biography] Vol. 2. Arkhangelsk. URL: http://doykov.com/tag/pitirim-sorokin/ (accessed: 25.11.2015).

Golosenko I.A., N.I. Serbenko (1999). Petrazhitskiy Lev Iosifovich [Petrazycki Leon I.] / Zh.T. Toshchenko et al., eds. Sotsiologi Rossii i SNG XIX-XX vv. Biobibliograficheskiy spravochnik [Russian and CIS Sociologists of the XIX-XX centuries. Bio-bibliographic reference book]. Moskva: Editorial URSS: 232-233.

Gordon M.K. (1949). [Review of] Europe on the move. War and population changes, 1917-47 by Eugene M. Kulischer // Russian review. 8(1): 87-88.

Gurvitch G.D. (1942). Pamyati professora A.M. Kulishera [In memory of Professor A.M. Kulischer] // Novyy zhurnal [New Journal]. 2: 374-375.

Hessen S.I. (2011). Sovremennaya demokratiya [Modern democracy] // Kantovskiy sbornik [Kant collection]. 3: 93-97.

Hoffmann-Nowotny H.-J. (2000). Demography and sociology / Z. Pavlik, ed. Position of demography among other disciplines. Prague: Charles University, Department of demography and geodemography: 73-79.

Khomenko A. (1925) Do pitannya pro suchasniy ríven' zagal'noï smertností na Ukraïní [On the question of the general mortality level in Ukraine]. Kharkov: TsSU URSR [Central Statistical Agency of Ukrainian Soviet Socialist Republic].

(1980). K voprosu ob urovne obshchey smertnosti na Ukraine [On the question of the general mortality level in Ukraine] / Khomenko A.P. Sem'ya i vosproizvodstvo naseleniya (Izbrannyye proizvedeniya) [Family and population reproduction (Selected Works)] / V.S. Steshenko, ed. Moskva: Statistika: 96-119.

Kirk D. (1944). Population changes and the postwar world // American sociological review. 9(1): 28-35.

Kula W. (1950). Histoire des Institutions: Époque contemporaine // IX Congrès international des sciences historiques : Rapports. Vol. 1. Paris : Armand Colin : 472-503. 
Kulischer A.M. (Kulisher, Koulicher, Koulisher) (1915). Avtonomiya Irlandii: otdel'nyy ottisk iz zhurnala [The autonomy of Ireland: offprint from the journal "Yuridicheskiy Vestnik" 1914, VI (II) and 1915, IX (I). Moskva: G. Lissner and D. Sovko].

(1921). Das Wesen des Sowjetstaates. Berlin: Verlag für Politik und Wirtschaft.

(1923). Lord Beaconsfield, 1804-1832. Berlin: Rimon (published in separate editions in Hebrew and Yiddish).

(1924). La théorie des mouvements des peuples et la guerre civile en Russie // Revue internationale de sociologie. 32: 492-507.

(1925). P.G. Vinogradoff // Posledniye novosti [The latest news]. Paris, 1925.

December 22: 2.

(1927a). Postoyannoye [The permanent// Posledniye novosti [The latest news]. Paris, 1927. November 6: 3 .

(1927b). Contribution to discussion on optimum population and food supply / M. Sanger, ed. Proceedings of the World Population Conference. London: Edward Arnold: 102-103.

- (1927c). Some aspects of the migration problem / M. Sanger, ed. Proceedings of the World Population Conference. London: Edward Arnold: 305-309.

(1928). Les guerres et les migrations // VI ${ }^{\mathrm{e}}$ Congrès international des sciences historiques. Résumés des communications présentées au Congrès. Oslo : 29-30.

(1932). Les quatre constitutions de l'Angleterre // Archives de philosophie du droit et de sociologie juridique. 2(3-4) : 480-529.

(1933). Le cycle de population dans les pays modernes // VII ${ }^{\mathrm{e}}$ Congrès international des sciences historiques. Résumés des communications présentées au Congrès. Vol. II. Varsovie : 354-355 (see this article in the Appendix).

(1934a). La multiplicité des sources en droit constitutionnel // Le Problème des Sources du Droit Positif. Annuaire de l'Institut international de philosophie du droit et de sociologie juridique, 1934-1935. Paris : 209-227.

(1934b). [Review of] A. Landry. "La Révolution démographique. Études et essais sur les problèmes de la population". Paris : Sirey. 1934, 230 p. // Archives de philosophie du droit et de sociologie juridique. 1934. 4(1-2) : 257-259 (see this article in the Appendix).

(1935). La Démocratie anglaise et le droit de dissolution // L'Année politique française et étrangère. 10(2): 97-130.

Kulischer A.M., E.M. Kulischer (1932). Kriegs- und Wanderzüge. Weltgeschichte als Völkerbewegung. Berlin - Leipzig: Walter de Gruyter.

Kulischer J.M. (2012). Istoriya ekonomicheskogo byta Zapadnoy Yevropy [History of economic life in Western Europe]. 10th ed. Chelyabinsk: Sotsium. For the first German edition of the book prepared by the author himself, see: Kulischer J.M. (1928-1929). Allgemeine Wirtschaftsgeschichte des Mittelalters und der Neuzeit. Bd. I-II. München -Berlin: R. Oldenbourg.

Kulischer E.M. (1928). Die Richtungen der Völkerbewegungen // VI Congrès international des sciences historiques. Résumés des communications présentées au Congrès. Oslo: 30-33. 
(1948). Europe on the move: War and population changes, 1917-1947. New York: Columbia University Press.

Kulischer M.I. (1887). Ocherki sravnitel'noy etnografii i kul'tury [Essays on comparative ethnography and culture]. St. Petersburg: I.N. Skorokhodov.

Landry A. (1909). Les trois théories principales de la population // Scientia. 6(11) : 3-29.

(1933). La révolution démographique // Economic essays in honour of Gustav Cassel. London : George Allen \& Unwin: 357-367.

(1934). La révolution démographique. Études et essais sur les problèmes de la population. Paris : Librairie du Recueil Sirey.

(1982). La révolution démographique. Études et essais sur les problèmes de la population. Paris: INED.

Matiyeva A.Kh. (2008). Biblioteka M.M. Kovalevskogo v fonde Otdela redkikh knig i rukopisey Nauchnoy biblioteki MGU (Okonchaniye) [Library of M.M. Kovalevsky in the fund of the Department of rare books and manuscripts of the Moscow State University science library (Completion)] // UNIVERSITATES. Nauka i prosveshcheniye [Science and education]. 1: 50-59.

Milyukov P. (2015). Novoye ob'yasneniye khoda vsemirnoy istorii (Predisloviye, podgotovka teksta i kommentarii M. Tol'tsa) [New explanation of the course of World history (Introduction, preparation of the text and commentary by M. Tolts)] // Demograficheskoye obozreniye (Demographic review). 2(2): 106-120. URL: http://demreview.hse.ru/2015-2/167985104.html (accessed: 25.11.2015).

Pavlik Z. (1981). Zákonitosti vyvoje demografických systému (Patterns of a demographic system) // AUC Geographica. 1: 3-31.

Perepiska V.A. Borisova s Leonom Rabinovichem-Radzinovichem i A. Shubrtovoy [Correspondence of V.A. Borisov with Leon Rabinowicz-Radzinowicz and A. Shubrtova] (2007) // V.A. Borisov. Demograficheskaya dezorganizatsiya Rossii: 1897-2007. Izbrannyye demograficheskiye trudy [The demographic disorganisation of Russia: 1897-2007. Selected demographic works]. Moskva: NOTA BENE: 498-502.

Rabinowicz L. (1929). Le problème de la population en France précèdé d'une histoire générale de la population. Étude de sociologie de la population. Paris: Marcel Rivière.

Rabkin L. (2015). Anti-Semitism / J. Ciment, ed. Encyclopedia of the Jazz Age: from the end of World War I to the Great Crash. London - New York: Routledge: 67-68.

Russkiy Berlin [Russian Berlin] (2003) / Sost., predisl. i personalii V.V. Sorokina. [Compilation, foreword and biographies by V.V. Sorokina. Moskva: Moscow University.

Sauvy A. (1963). Malthus et les deux Marx. Paris: Denoël.

Serkov A.I. (2001). Russkoye masonstvo. 1731-2000 [Russian Freemasonry. 1731-2000] // Entsiklopedicheskiy slovar' [Encyclopaedic dictionary]. Moskva: ROSSPEN.

Shul'govskiy N.N., compiler (1910). Kruzhok filosofii prava professora L.I. Petrazhitskogo pri SPB universitete za desyat' let sushchestvovaniya [Philosophy of law study group of Professor L.I. Petrazycki at St. Petersburg University for the ten years of its existence]. St. Petersburg: Pravo.

Simpson J.H. (1939). The refugee problem: report of a survey. London - New York: Oxford University Press. 
Sorokina M.Yu. (2003). Krugi zhizni Nikolaya Martinovicha - uchenogo, diplomata, emigranta [The life circles of Nikolai Martinovich - scientist, diplomat, emigrant] / D.D.

Tumarkin,compiler and ed. Repressirovannyye etnografy: vyp. 2 [Repressed ethnographers: issue 2]. Moskva: Vostochnaya literatura: 347-374.

Subrtova A. (1984). Teorie demografické revoluce: prispevek ke genezi [Theory of demographic revolution: a contribution to the genesis] // Demografie. 36(3): 193-199.

Szreter S. (1993). The idea of demographic transition and the study of fertility change: a critical intellectual history // Population and development review. 19(4): 659-701.

The Gazette (1942). Montreal, 1942. October 26: 22.

Thompson W.S. (1929). Population // American journal of sociology. 34(6): 959-975.

Tolts M. (2014). Vklad sem'i Kulisherov v mirovuyu migratsiologiyu [The Kulisher family's contribution to the world migration studies] // Demoscope Weekly. 603-604. URL: http://demoscope.ru/weekly/2014/0603/nauka04.php (accessed: 25.11.2015).

(2015a). Avtor termina "peremeshchennyye litsa": Yevgeniy Mikhaylovich Kulisher [The author of the term "displaced persons": Eugene M. Kulischer] (1881-1956) // Demoscope Weekly. 655-656. URL: http://demoscope.ru/weekly/2015/0655/nauka05.php (accessed: 25.11.2015).

(2015b). Zabytyy entsiklopedist: Mikhail Ignat'yevich Kulisher [Forgotten polymath: Mikhail I. Kulischer] (1847-1919) // Yevreyskaya Starina [Jewish Antiquity]. 2. URL: http://berkovich-zametki.com/Starina0.php?srce=85 (accessed: 25.11.2015).

Vengerov S.A. (1919). Na venskom literaturnom kongresse 1881 goda [At the Vienna Literary Congress 1881] // Vengerov S.A. Sobraniye sochineniy [Collected Works]. [V 5 t. (5 volumes)]. 2nd ed. Vol. 4. Petrograd: Svetoch: 103-150.

Vinogradoff P.G. (2014). Ocherki po teorii prava [Essays on the theory of law]. 2nd ed. Moskva: LENAND.

Vinogradov S.M. (2003). I.M. Kulisher kak istorik-ekonomist [I.M. Kulisher as historian and economist] / E.I. Kolchinsky, I.P. Medvedev, eds. Russkaya nauka v biograficheskikh ocherkakh [Russian science in biographical sketches]. St. Petersburg: Dm. Bulanin: 221-234.

Vozrozhdeniye [Renaissance] (1936). Paris, 1936. 4 April: 2.

Vremennoye Pravitel'stvo i Uchreditel'noye Sobraniye [The Provisional Government and the Constituent Assembly] (1928) // Krasnyy Arkhiv [Red Archives]. 3: 107-141. 


\title{
APPENDIX
}

Below are the original French texts of the summary of Alexander Kulischer's report at the VII International Congress of Historical Sciences (Warsaw, 1933) and his review of Adolphe Landry's book, La révolution démographique, discovered by Mark Tolts.

\section{LE CYCLE DE POPULATION DANS LES PAYS MODERNES}

\author{
Alexandre M. Koulicher \\ VII Congrès international des sciences historiques. Résumés des communications \\ présentées au Congrès. Vol. II. Varsovie 1933 : 354-355.
}

La plupart des peuples modernes traversent à différentes époques, suivant le moment où le peuple en question est entré dans la voie du «progrès moderne», un cycle typique au point de vue du développement de la population. En parlant de l'Angleterre, où ce cycle a commencé dès la seconde moitié du XVIIIe siècle, il se répète avec une régularité étonnante des stages dont il consiste, chez les autres peuples européens, généralement parlant, de l'ouest à l'est.

Ce cycle, qui, aujourd'hui, s'achève chez les peuples les plus avancés à ce point de vue, tandis qu'il est encore en plein développement chez les autres, consiste des stages suivants. En une première période, la population augmente de plus en plus rapidement grâce à une baisse prolongée de la mortalité. Une baisse de la natalité commence aussi, mais à une certaine distance et elle va, d'abord, plus lentement de sorte que l'excédent des naissances est toujours accru et il y a une véritable «inondation" du pays. Plus tard, l'augmentation est de plus en plus enrayée, par la baisse de la natalité rattrapant celle de la mortalité, bien que celle-ci continue, elle aussi, de diminuer. La proportion de l'augmentation est réduite bien que ses chiffres absolus continuent de croître. A la fin, il y a une baisse foudroyante de la natalité, qui tend à supprimer tout excédent des naissances et fait même prévoir une diminution de la population.

De ce développement normal il y a pourtant quelques exceptions. Ainsi, d'un côté, en Hollande, la baisse de la natalité n'a pas pu jusqu'ici rattraper celle de la mortalité et le développement de la population demeure progressif sans arrêt. D'autre part, en France, la baisse de la natalité a rapidement gagné sur celle de la mortalité de sorte qu'il n'y a pas eu de période d'excédents de naissances augmentés, rien qu'une diminution suivie de cet excédent, jusqu'à l'état stationnaire de la population, qui s'est établi en France avant les autres pays, mais auquel d'autres peuples arrivent également après des secousses et des tribulations beaucoup plus grandes.

Les causes de ce cycle se trouvent dans certaines relations entre le mouvement démographique et l'évolution économique des pays modernes, - en particulier, dans le processus également typique de l'exode rural et de l'urbanisation des populations.

La conclusion générale qui se dégage de l'étude de ce sujet, consiste en ceci, que les changements de la natalité, loin d'être le facteur déterminant de l'évolution, n'en sont que des conséquences, étant déterminés, d'une part, par les conditions économiques qui limitent, à tout moment donné, le nombre de la population additionnelle, susceptible d'être élevée sur le produit du travail de la population existante, et d'autre part, dans ces limites par la mortalité, qui subit, 
beaucoup plus directement l'influence de l'évolution économique et intellectuelle, la restriction des naissances ne faisant que permettre le maintien d'une mortalité réduite.

\section{REVIEW OF THE BOOK BY ADOLPH LANDRY LA RÉVOLUTION DÉMOGRAPHIQUE}

\section{A. Koulicher (Kulischer)}

Archives de philosophie du droit et de sociologie juridique. 1934. 4(1-2) : 257-259

A. Landry. - La Révolution démographique (Etudes et essais sur les problèmes de la population). Libr. du Recueil Sirey, 1934, 230 pp.

L'ouvrage de M. Landry est un recueil de plusieurs études. Le thème principal en est le fait mondial de la diminution des naissances et l'examen des moyens destinés à combattre cette révolution, tenue pour néfaste par notre auteur qui est «un populationniste».

Ouvrage d'une valeur scientifique très supérieure à la plupart des écrits de l'école nataliste. M. Landry cède bien au parti-pris, traditionnel en France depuis l'époque où la stagnation numérique de la population française par suite de la diminution des naissances était considérée comme un fait exceptionnel de décadence d'une race vieillissante condamnée à la submersion par les peuples plus jeunes et plus vigoureux. Mais ce parti-pris n'empêche pas l'auteur d'exposer avec beaucoup de vigueur les faits nouveaux qui sont venus démolir cette ancienne conception. Non seulement, en effet, la «révolution démographique» se présente aujourd'hui comme un phénomène universel, bien qu'elle fasse son apparition chez les différents peuples à des moments différents, mais il semble en outre qu'elle marche d'autant plus vite, qu'elle a commencé plus tard dans un pays donné. Aussi la situation démographique de plusieurs pays européens est-elle dès maintenant «pire» que celle de la France. Et M. Landry ne cache pas sa crainte que le monde entier puisse succomber au même destin. C'est sans ménagement pourtant qu'il décrit le «régime démographique» du bon vieux temps auquel met fin la «révolution» tant redoutée : «Là, aucune préoccupation des conséquences que peut avoir pour le bien-être des individus, des familles, la multiplication sans frein des membres de celles-ci.» L'adaptation du chiffre de la population à ses ressources économiques se fait sous ce régime par la mortalité, - y compris les grandes famines et épidémies, - lesquelles rattrapent la natalité, et «enrayent l'accroissement».

On conviendra qu'il est malaisé de préconiser le retour à ce «régime démographique primitif». C'est sans doute le motif pour lequel l'auteur cherche à définir un «régime intermédiaire». Là un certain souci de maintenir le niveau du bien-être conduirait au retardement des mariages ou au célibat de quelques-uns. Ce régime serait à distinguer du «régime contemporain», résultat du triomphe d'une conception «rationnaliste» de la vie, qui conduit à la prévention directe des naissances. Une baisse de la mortalité produit, sous le régime «intermédiaire», un accroissement de la population; ce n'est plus le cas sous le régime «contemporain».

Un exemple du «régime intermédiaire» serait fourni par l'Angleterre au XIX $\mathrm{X}^{\mathrm{e}}$ siècle à une époque où le «régime contemporain»s'était déjà établi en France. En réalité, il ne s'agit pas de 
deux stages, mais de deux variantes de la «révolution démographique», la variante anglaise s'étant reproduite plus tard dans les autres pays, où la «révolution» s'est accomplie. En France seulement, la restriction des naissances est apparue, dès le début, dans les villes et les campagnes à la fois. Embrassant tout le pays, la baisse des naissances a diminué progressivement le taux d'accroissement, malgré la baisse de la mortalité, jusqu'à aboutir sans secousses à l'état de population stationnaire. De là aussi la conservation des petits patrimoines et un moindre degré de prolétarisation. Partout ailleurs, la restriction des naissances n'était, d'abord, qu'un phénomène de la ville inondée par la marée, qui venait de la campagne, qui, elle, suivait encore la «loi naturelle», et n'échappait aux conséquences du «régime primitif» que par cette migration et, aussi, par l'émigration transocéanique. Dans ces conditions, la baisse de la mortalité commençait par augmenter l'excédent des naissances, celle de la natalité ne suivant qu'à distance. Puis, le déplacement rapide du centre de la population vers les villes infécondes a fait pencher brusquement la balance. De là, finalement, une baisse foudroyante de la natalité générale, d'où attente de diminution de la population à une époque prochaine.

M. Landry présente une bonne explication des méthodes employées pour calculer les tendances futures du développement d'une population. Les taux «bruts» de natalité et de mortalité sont trompeurs parce qu'ils dépendent de la distribution de la population entre les âges, cette distribution étant, elle-même, appelée à changer par suite de variations des éléments démographiques. Force est donc de remplacer le taux de la natalité par un calcul compliqué de la «reproduction» d'une génération par les femmes de la génération précédente, la mortalité entrant dans ce calcul, en tant qu'elle empêche une partie des femmes d'achever pleinement leur carrière «reproductrice». Quant à la mortalité générale (dont on «rectifie» le taux par un calcul de la durée moyenne de la vie), elle «n'est pas sans intérêt», mais les changements n'en conduisent qu'à des variations du nombre de la population, «une fois acquises». Il y a là des expressions qui prêtent à un malentendu. Ce que l'auteur veut dire, c'est que, lorsque la mortalité, après avoir subi un changement, redevient stable, la variation du nombre de la population, résultant de ce changement étant une fois accomplie, la tendance ultérieure de la population à augmenter ou à diminuer ne dépendra plus que de sa «reproductivité». Oui, mais la croissance sera plus rapide ou la diminution plus lente si la vie de chaque génération est plus longue. «L'intérêt» véritable de la mortalité réside en ceci, que tous les accroissements considérables de la population sur lesquels nous possédons des renseignements tant soit peu sûrs, ont été le résultat de la baisse de la mortalité qui ont fait doubler le genre humain au XIXe siècle, malgré tous les affaiblissements de la «reproductivité». A l'inverse, dans tous les cas, où nous connaissons avec certitude les causes de «dépopulations et de décadences», elles ont été produites par des vagues de mortalité exorbitante, sinon par la fuite des habitants; ces pertes devenaient définitives si elles coïncidaient avec la ruine des ressources économiques, double résultat caractéristique de tant de dévastations guerrières. Il y a des faits bien mieux prouvés que l'hypothèse d'une crise de naissances pour expliquer la décadence romaine.

Voilà pourquoi il y a plus d'urgence dans le danger des tentatives d'expansion violente de la part de populations surabondantes et qui continuent d'augmenter (par le fait des taux «bruts» d'excédents de naissances, lesquels en fin de compte, déterminent la situation actuelle à la différence de ces calculs «rectifiés» qui ne servent qu'à des pronostics douteux), - même au point de vue d'un idéal «quantitatif» de civilisation, - que dans la perspective lointaine d'une diminution du genre humain par la baisse des naissances. Reste, il est vrai, cette considération, que «du point 
de vue national, on sera très généralement populationniste». À un tel degré, ajoutons-nous, que l'on voit, à l'heure actuelle, dans quelques pays d'Europe les dirigeants, les intellectuels et démographes «nationaux» attelés à une double besogne: convaincre le peuple de la nécessité absolue de chercher des issues pour une population qui «étouffe» de plus en plus en ses limites (ce qui est démontré par les chiffres «bruts» de la population et de son accroissement), se préparer à la conquête de ces issues aux dépens des peuples vieillis» ou des races «inférieures»..., et, en même temps, mener une politique et une prédication «nataliste» à outrance, sous l'empire de la crainte folle que les «ravages» de la «révolution démographique» ne suppriment bientôt (comme il est à prévoir d'après les calculs de «reproductivité») et les moyens et les motifs des entreprises expansionnistes. Dans ces conditions, ne faut-il pas rejeter l'intérêt solidaire des «populationnistes» de tous les pays, se placer à ce point de vue humain, - identique, dans l'espèce, avec l'intérêt national de la France et de tous les peuples pacifiques, - qui fait ardemment souhaiter, dans ces cas, le triomphe de la «révolution démographique» aussi rapide que possible? 